\title{
The "BIT TAX": the case for further research
}

Citation for published version (APA):

Soete, L. L. G., \& Kamp, K. (1996). The "BIT TAX": the case for further research. MERIT, Maastricht Economic Research Institute on Innovation and Technology. MERIT Research Memoranda No. 012 https://doi.org/10.26481/umamer.1996012

Document status and date:

Published: 01/01/1996

DOI:

10.26481/umamer.1996012

Document Version:

Publisher's PDF, also known as Version of record

\section{Please check the document version of this publication:}

- A submitted manuscript is the version of the article upon submission and before peer-review. There can be important differences between the submitted version and the official published version of record.

People interested in the research are advised to contact the author for the final version of the publication, or visit the DOI to the publisher's website.

- The final author version and the galley proof are versions of the publication after peer review.

- The final published version features the final layout of the paper including the volume, issue and page numbers.

Link to publication

\footnotetext{
General rights rights.

- You may freely distribute the URL identifying the publication in the public portal. please follow below link for the End User Agreement:

www.umlib.nl/taverne-license

Take down policy

If you believe that this document breaches copyright please contact us at:

repository@maastrichtuniversity.nl

providing details and we will investigate your claim.
}

Copyright and moral rights for the publications made accessible in the public portal are retained by the authors and/or other copyright owners and it is a condition of accessing publications that users recognise and abide by the legal requirements associated with these

- Users may download and print one copy of any publication from the public portal for the purpose of private study or research.

- You may not further distribute the material or use it for any profit-making activity or commercial gain

If the publication is distributed under the terms of Article $25 \mathrm{fa}$ of the Dutch Copyright Act, indicated by the "Taverne" license above, 


\section{The "BIT TAX": the case for further research"}

Luc Soete and Karin Kamp

MERIT

University of Maastricht

PO Box 616

6200 MD Maastricht, The Netherlands

12 August, 1996

*This first draft is sent around for comments and reactions. So far the paper has greatly benefited from the many discussions with friends and colleagues and the many Internet responses. More than is usually the case, it is appropriate to emphasize that the sole responsibility for some of the "stupid, but dangerous" (skippy@ird.ita) ideas expressed in this paper remain solely with the first named author. 


\section{Introduction}

The report "Building the European Information Society for Us All" -- a "first reflections" report of an independent group of experts ${ }^{1}$ established by the European Commission to advice on the social and societal aspects of the information society -- contains a recommendation for the investigation of "appropriate ways in which the benefits of the Information Society (IS) can be more equally distributed between those who benefit and those who lose. Such research should focus on practical implementable policies at the European level, which do not jeopardise the emergence of the IS. More specifically, the expert group would like the Commission to undertake research to find out whether a "bit tax" might be a feasible tool in achieving such redistribution aims." Despite the prudence of the recommendation's language, the reference to the idea of a "bit tax" ${ }^{2}$ has led to considerable reaction amongst the press, policy makers and individual Internet users. Such reactions range from immediate adherence and even proposals for implementation ${ }^{3}$, to disbelief and disgust. As chairman of the socalled High Level Expert Group ${ }^{4}$ and the person most eager to have this recommendation included in the report, I am particularly keen on elaborating on the idea of the "bit tax" following the policy reaction and press reports regarding what has been called by some a new "Loch Ness" tax monster".

Perhaps it is not surprising that in the present, global free market environment, any suggestion for a new tax is likely to be greeted with scepticism and to be quickly rejected. The fact that the first thing a group of "high level" experts on the Information Society would come up with, is a tax on the transmission of information creates understandably some level of disbelief See Building the European Information Society for Us All, First Reflections of the High Level Group of Experts, DG V, Brussels, January 1996.

2 The idea of a "bit tax" was, as noted in the experts' group report, first put forward by Arthur Cordell and Thomas Ide in a Club of Rome report dated November 1994. A more elaborated version can be found in Cordell and Ide, 1995.

As in the case of the Belgian Minister for Telecommunications Di Rupo at a conference on teleworking (see Le Soir, June 6, 1996).

See Le Soir, June 11, 1996.
} 
particularly from those who have set their hopes for a renewed expansion of economic growth in Europe and elsewhere in the world on the current wave of new information and communication technologies ${ }^{6}$. More surprisingly though, in the case of the "bit tax" proposal, is that the simple recommendation to research the feasibility of such a new tax has been rejected by some at the outset for fear that "it might give the wrong signal" to potential investors $^{7}$. Less surprisingly are the extremely negative responses of individual Internet users. The individual responses received thus far on e-mail -- ranging from "you schmuck" to "hands-off the Internet" -- all fear the possible attempt of the state to tax both communication and freedom of speech. Finally, on the side of the technical experts, the reaction has also been by and large negative: "bits" are or will soon be an irrelevant measure of transmission intensity; bits are difficult if not impossible to monitor; "broadband" capacity is in effect infinite; etc.

Before being convinced by all these (too?) quick responses and foreclosing even the research option on the "bit tax", we summarize briefly in these couple of pages the main arguments in favour of such a tax, and why it is, in our view at least, an essential part of the distributional challenges of the emerging 'information society ${ }^{8}$. By doing so, we put forward a highly personalized "vision" of the aim, nature and possible uses of a "bit tax". Let the traditional policy reader thus be warned: apart from a few papers by Cordell, there is virtually no literature on this subject. This is a "no-man's research" land". For this reason only the EU experts' group request for further research seems to be more than justified.

$6 \quad$ We are reminded of the story told by Nathan Rosenberg about the response of Faraday to the sceptical politician who asked Faraday after he had discovered the basic principle of electricity (electromagnetic induction in 1831) what it was good for: "Sir, I do not know what it is good for. But of one thing I am quite certain, some day you will tax it." (Rosenberg, 1996).

7 See the official press reaction of the Flemish government: "Bit tax boort inspanningen van de Vlaamse regering de grond in (Bit tax undermines the efforts of the Flemish government)", Brussels, June 12, 1996. "Living and Working in the Information Society: People First", 22 July 1996.

While there is a growing literature on Internet pricing and a lot of discussion on the Net of the advantages of "usage-based" versus the "flat rate" pricing (see a.o. MacKie-Mason and Varian, 1994 and Brody, 1995), there has been very little written about alternative taxation systems on the Net. The most recent message found (5 August, 1996) announced that the Interactive Service Association (ISA) will prepare a White Paper on state and local taxation of online and internet services. 


\section{The aim: the "bit tax" as part of a shift in the tax base of society}

The main economic argument for a "bit tax" is fairly straightforward. As our economy becomes more and more characterised by the production, distribution and consumption of intangibles from an economy that was characterised by the production, distribution and consumption of tangibles, it seems relevant to question whether or not the present tax base remains adequate. Historically, the goods we consumed were physical and therefore the production, distribution and consumption of these goods was easily taxable. The inputs required for production could be easily measured, the value added generated through the whole industrial and distribution process easily traced and the final consumption easily located. Today, as economic activity becomes increasingly concentrated in immaterial information transactions, large parts of these value chains appear invisible; so invisible that a substantial part evaporates, incorporated in material goods or services, in the end hidden in an unmeasured, but not unnoticed, increased consumer surplus.

These invisible gains are, as has been argued at length in the recent OECD report on Technology, Productivity and Job Creation, behind the so-called Solow paradox ${ }^{10}$-- the fact that we do not seem to notice in official statistics the benefits of the new information and communication technologies. They are also, as increasingly acknowledged in the US ${ }^{11}$, behind the significant "overestimation" of inflation in the official Consumer Price Index figures, whereby the growing consumer surplus associated with new and better goods and services have been systematically ignored. Hence, there is, as argued by Cordell, at least a suspicion that part of the productivity and consumer gains from the new information and communication technologies has disappeared into the production and distribution networks and have not been reflected in lower prices or higher profits or salaries.

At the same time, goods that were traditionally distributed physically are becoming

10

Named after Robert Solow after his observation that: "Everywhere around us we see computers except in the productivity statistics" (see "The OECD Jobs Strategy, Technology, Productivity and Job Creation", 1996). Finance Committee, 13 March 1995 and L. Nakamura, Federal Reserve Bank of Philadelphia, working paper no. 95-21, "Is US Economic Performance Really That Bad?", October 1995. 
increasingly available via the networks. The taxing of the distribution of these goods, which has traditionally formed one of the essential bases for national, state or even local government's tax revenues is, as a result, eroding rapidly. It has been estimated that in the US the use of the Internet by individual consumers accessing mail order companies, exempt from sales taxes, has meant a reduction in state sales taxes revenues of over $\$ 3$ billion in $1995^{12}$

More generally, it can be argued that the simple fact of not adjusting a nation's tax basis will automatically imply a non-neutrality of different distribution or communication systems; the newest communication systems avoiding, either by accident or by design, the prevailing tax levying system. The difference between the US sales tax system and Europe's VAT system is illustrative in this regard. In the US, it is by and large by accident -- the mail order companies local sales tax exemption -- that electronic distribution is eroding local sales taxes; in Europe it is the levying of VAT on services (banking, insurance, telephone, etc) which is becoming avoided because of the global access and footloose location possibilities of such service providers through Internet. At the same time, providers of goods and services using traditional means become less competitive since they must pay taxes on their visible and easily traceable goods or services. Send a letter through the post or special delivery and tax will be paid on the stamp or delivery bill; make a telephone call, and at least in Europe VAT will be levied on the phone bill; order the experts' group report "Building the European Information Society for Us All" from the EU, and VAT will be paid on postal costs. Via electronic means, however, the tax rate on all these transactions is practically nil (with the exception of the VAT on the couple of seconds of dial-up and local telephone costs). Furthermore, since there will be less physical distribution of these goods, less revenues from sales or VAT taxes will be earned ${ }^{13}$.

More generally, it can be stated that in the current configuration of governments' methods of raising revenues from the distribution of goods and services, electronic networks are likely

\footnotetext{
12 See Newman, N., "The Great Internet Tax Drain", Technology Review.

13 When the Financial Times is read on the Internet, the actual (physical) newspaper is not bought. The tax that would have been paid on the physical newspaper is "lost".
} 
to systematically lead to less taxes to be charged and collected.

The main economic argument for a shift in the tax base away from tangibles towards intangibles is thus simple. Just as one to two hundred years ago, economic discussions were dominated by the "corn tax" reflecting the importance of grain for the national economy, today, the dominant issue should be how governments can adjust their tax base in line with the changing economic structure towards an information society and the increasing importance of information transmission for economic production and consumption. Shifting tax revenues on the basis of a tax on the individual electronic "bits" or "bytes" appears from the outset the most straightforward and logical taxing method. As Cordell puts it: "The new wealth of nations is to be found in the trillions of digital bits of information pulsing through global networks. These are the physical/electrical manifestation of the many transactions, conversations, voice and video messages and programs that, taken together record the process of production, distribution and consumption in the new economy....The value that is added comes from interactivity. It is this value that provides the productivity in networks." ${ }^{14}$ The analogy between taxes on "motor highways" and "information highways" is from this perspective illustrative. As in the case of the automobile, gasoline or bridge taxes are being paid on physical highways, where on the information superhighway digital traffic is being taxed per bit.

\section{On the nature of the "bit tax": from taxing value added to taxing transmission}

As mentioned above, the main consumption/production tax levied in the EU countries is the Value Added Tax (VAT). The latter provides an increasingly harmonized tax base for the individual member countries allowing goods and services to be taxed at their various points of production and value added creation. A VAT-system is ideal in the case of material goods or services being produced. The "value added" contributions of the various intermediary inputs are relatively easily quantifiable, the value of the final good or service consisting in a relatively straightforward manner of the amalgamation of these various inputs. 
In the case of information and communication services it is very difficult to talk in any real or meaningful way about a tax on "value added". Taxing the "value added" of a telephone conversation by levying a certain tax percentage on the bill of a telephone call has little meaning to it. The cost of the communication will have no relationship to the possible value of the communication, but rather be a function of the distance (local/long distance) and time (seconds/minutes) of the communication.

We propose that the "bit tax" fits within a broader idea to replace value added tax based systems on immaterial goods and services with a transmission based tax system, i.e. a system by which the tax is levied as a proportion of the "intensity" of the information or communication transmission. The number of bits or bytes is considered as a more representative unit to provide an indication of such transmission intensity than time or distance. Only in the case of communication systems using a constant number of bits per second, such as a telephone conversation, will there be a straightforward relation between time and transmission intensity.

In other words, a "bit tax" would not be related in any direct way to the actual "value" of a communication, rather it would focus on the transmission of information. From this perspective it is the number of bits that "count", whether transmitted at a constant rate over time as in a telephone communication or in packages over the broadband as on Internet. In practical terms a "bit tax" proposal would thus involve the introduction of "bit measuring" equipment on all communication equipment (similar to the case of electricity metres) ${ }^{15}$, thus enabling consumers and users the monitoring in volume terms of bits whether they are transmitted by line or satellite. It would make no difference if a user accessed an e-mail message from a friend or a huge financial transaction. The amount paid would only be based on the number of bits transmitted.

15 That this is not a completely blue sky idea is illustrated by the acknowledgement in the debate surrounding usage-based pricing that Internet use will have to become "metered, with users paying by the message, by the byte, or by the Web page, just as they now pay by the kilowatt-hour for electricity" (Brody, H. "Internet@ crossroads.\$\$", Technology Review, May/June, 1995. 
The amount would be kept very low, Cordell proposed a tax of .000001 cents/bit ${ }^{16}$ (or 1 cent per megabit), without anybody really knowing what the effect of this would be in terms of total government revenue or individual user or company cost. In a recent intervention at a conference on teleworking, the Belgian Minister for Telecommunications Di Rupo referred to a total figure of $10^{18}$ bits being transmitted in and out of Belgium. At the Cordell rate, this would imply a substantial amount of additional government tax revenues: some $\$ 10$ billion or some $4 \%$ of Belgium's GDP. At a recent data base conference, Lewis Platt, CEO and Chairman of Hewlett-Packard, indicated that HP used currently its intranet main backbone at a rate of some 5 terabytes a month (or 480 terabits a year). Assuming for a moment that these intranet bits could be monitored, this would imply that HP would pay a total "bit tax" bill of some $\$ 4.8$ million on total world wide revenues for HP in 1995 of some $\$ 32$ billion and profits of some $\$ 5$ billion. In other words a tax bill of less than $.1 \%$ of current profits. What a "bit tax" would amount to with respect to individual users is more difficult to calculate, even though the surfing or transferring of particular sets of information can easily be calculated. Many individual users may be happy to know, for example, that the "bit tax" cost for downloading Pamela Andersen's latest swimsuit pose would be less than half a cent.

However, a more pragmatic method more in line with the idea of the "bit tax" replacing all VAT on information and communication services, might imply the identification of a tax rate level per bit that would be more or less equivalent to the total VAT cost on an average user's telephone bill. This way one might avoid some of the (much exaggerated ${ }^{17}$ ) negative reactions on the possible negative impact a "bit tax" might have on the future development of "call centres" and other new information service based activities popular in many of the regional European development plans, and looked upon as the main new employment providers of the future.

But to discuss these as well as other practicalities amounts at this stage to not much more than "blue sky" speculation. We have not addressed, "faute d'expertise", the technical issues

16 See Tobin's calculations in "Speculator's Tax" in New Economy, 1994, The Dryden Press.

17 The argument of the Flemish government that "a "bit tax" amounts to taxing the employment of the future in order to maintain employment of the past" is a good illustration of such exaggeration. 
involved. Obviously it is easy to dismiss the whole "bit tax" idea on technical grounds, whereby "bits", for example, can no longer be monitored such as in the case of satellite communication. However, the argument for the use of bits is that they are a readily available electronic unit measure reflecting data or information transmission. Obviously alternative measures might be or become more appropriate than the "bit" as a taxing unit. The main point is that there surely is one measure which would give some indication of transmission intensity even using satellite communication and whose monitoring is relatively straightforward. Such measures might currently not be recorded, but as mentioned earlier, the "bit tax" proposal does involve the design of new measuring instruments to record and trace transmission intensity. While we agree with those who question whether or not the "bit tax" revenues would be sufficiently high so as to cover these accounting $\operatorname{costs}^{18}$, this is precisely what the proposed research will need to figure out. The literature on new and alternative methods of pricing information and communication services may be of relevance here. To some extent the whole notion of an alternative taxing of information services is part of the much broader discussion of how we should price information in our societies, and in particular the possible shift towards usage-based pricing ${ }^{19}$.

Besides addressing issues of technical feasibility, the proposed research on the "bit tax" should identify an "optimal" tax rate, the costs for the average individual user, for small and large companies, and the total amount of additional tax revenues for the government. Only when this is done can a real discussion take place on whether and to what extent the "bit tax" proposal is likely to have negative effects on competitiveness, future employment, inflation, delocalisation, future use of Internet or even freedom of speech. To argue on a priori grounds that it will is foolish. To try to foreclose even the possibility to investigate the issue is even

18 The billing and accounting costs of telephony is said to represent more than half what customers pay for a telephone call. However, as argued by MacKie-Mason and Varian (Some FAQs about UsageBased Pricing, September 1994), the main reason for this is the fact that marginal costs are "so low, not because billing costs are so large. Since it costs almost nothing to make a call during non-peak periods, accounting costs are almost $100 \%$ of the incremental cost of a non-peak call!" As a percentage of total costs, MacKie-Mason and Varian estimate AT\&T's billing costs to be less than $10 \%$.

For further information see MacKie-Mason and Varian (1995); Gupta, Stahl and Whinston (1995); and Stahl (1995). The paper by MacKie and Varian "Some FAQS about Usage-Based Pricing", September 1994, referred to above contains a particularly useful overview of some of the advantages and disadvantages of usage-based pricing. 
more foolish and contrasts sharply with the creative challenges the Information Society is confronting us all with.

\section{On possible additional benefits of the "bit tax": reducing information pollution and congestion}

Compared to other taxes, such as the eco $\mathrm{CO}_{2}$-tax or even Tobin's "speculators" tax proposal, taxing the transmission of information does not, at least at first sight, involve the pricing of any negative externality, rather the contrary. The substitution of physical transport of persons or goods for electronic information transmission (as in the case of teleworking or at least partly in the case of teleshopping) is likely to reduce substantially the negative environmental and congestion externalities of cheap transport and the dramatic increase in mobility typical of society's post-war industrial development growth path. Therefore, at first sight, a "bit tax" proposal is not justified on the basis of negative externalities.

However, a "bit tax" might reduce one negative externality of network technologies with low or zero marginal costs: the rapidly growing congestion and increasing amount of "junk" and irrelevant information being transmitted. Congestion has become more serious as users increasingly access colour images, sound files, video - all with very high bandwidth applications. The increased number of users (in 1995 the Internet doubled in size, as it has done every year since 1988) adds to the congestion problem. Although technological developments will help to alleviate the problem, new subscribers combined with increased usage of "taxing" multi-media applications will also increase congestion. For this reason, there is general agreement amongst users as well as Internet experts that congestion will be an increasingly serious problem.

To address the congestion problem, some analysts have, actually, proposed setting up pricing schemes that charge based on usage ${ }^{20}$. The argument behind usage-based pricing starts from the assumption that even though bandwidth is continuously increasing, Internet is a scarce resource and it is unlikely that it will be able to "keep up with" demand growth. As Mackie- 
Mason put it: "congestion on the Internet is already hindering those that attempt to use applications during peak business hours. The problem becomes particularly acute when some special event occurs. After the comet Shoemaker-Levy struck Jupiter, for example, and people downloaded the dramatic telescope images, large portions of the Internet slowed down. In such situations, urgent transmissions, such as potentially lifesaving video conference between a surgeon and a radiologist, might queue up behind a home movie that someone put on the Net just for fun. In effect, the Net can be dominated by people with a lot of time on their hands, and there is no provision for buying one's way to the front of the line." ${ }^{21}$ More generally, there is quite some agreement amongst analysts that some type of disincentive is required to curb Internet consumption.

The main economic problem is that there is no incentive to be "economical" with information since the cost difference between sending 1 byte/second or 1 billion bytes/second is minimal, often close to zero. The opposite might actually be the case. As the High Level Expert Group report emphasized: "For us the distinctions between 'data', 'information' and 'knowledge' and between 'codified' and 'tacit' knowledge are of considerable importance. From our standpoint, the generation of unstructured data does not automatically lead to the creation of information, nor can all information be equated with knowledge. All information can be classified, analysed and reflected upon and otherwise processed to generate knowledge. Information, in our sense, is comparable to raw materials processed by industry to make useful products. One of the main effects of the new ICTs has been a billion-fold reduction in cost and speed of storing and transmitting information. However, such ICTs had no such effect on knowledge, still less on wisdom. ${ }^{22}$ One of the main problems for the IS, therefore, is to develop the skills and tacit knowledge to make effective use of this vast resource. Without such tacit knowledge, to navigate the rough seas of on-line information, with its misinformation, poor quality information, unreliable information and advertising hype could induce nausea." 23

21 See H. Brody, "Internet Crossroads", Technology Review.

22 "Which we would identify as "distilled" knowledge derived from experience of life, as well as from the natural and social sciences, from ethics and philosophy." of Experts, DG V, Brussels, January 1996, page 3. 
The ease and low cost of accessing information has certainly been behind the dramatic growth in Internet, mobile and other forms of electronic communication. At the same time, there is little doubt that the costs of selecting possibly relevant information have also risen rapidly. It is the well-known information paradox: as information becomes cheaper and more information becomes available, the cost of selecting relevant information and of taking time to reflect, rises rapidly. For example, in the "old days" people used to sit down, compose a letter, put it in an envelope and send it off. This slow communication system made people think twice before sending something out, often reflecting and questioning the value of what they were saying. Some older people much prefer to communicate by letter than by phone. The fact that post communication continued and still continues to exist for so long alongside telephone communication, illustrates to some extent the many complementary as opposed to purely substituting characteristics of voice and written forms of communication.

Today, thanks to the ease of forwarding messages and sending them to multiple parties at one time, little time for reflection is required, if not allowed for. Spontaneous, immediate near voice reaction has become the norm in e-mail communication: speed and volume at the expense of content and reflection. These new features of electronic communication are clearly advantageous: they are more environmentally friendly (no paper required), "number" efficient (no need to write the same message over and over), and quick (unlike postal service messages, they can be sent and received almost immediately). However, there are negative aspects associated with the overflow and time wasted on identifying and selecting possible relevant information, which we would identify as a problem of "information pollution". A "bit tax" might help, to some extent, in reducing this "information pollution".

In economic terms the use of marginal cost pricing of common, network goods such as Internet services may lead to what has been called a "tragedy of commons" - a situation where a common resource is overutilised causing unavoidable losses for society as a whole ${ }^{24}$. Economic theory teaches us that when confronted with such a negative externality, prices should exceed the marginal cost of production by the marginal social cost of congestion, reducing use of the resource to cases whereby the personal benefit to the conference on The Economics of the Information Society, 30 november 1995. 
consumer is greater than the social cost of usage. The "bit tax", minute as it is, can be interpreted as an estimate of the marginal social cost of congestion. Levying a "bit tax" would, in other words, force users to focus their use of Internet to activities with higher benefits than these marginal social costs.

Another area which might be positively affected by the "bit tax" is worker productivity. Some employers already complain that certain workers spend more time surfing the net, sending personal e-mails or playing "addictive" computer games than actually doing their jobs. While there is a learning component to such addiction, there is also a significant cost. With all these tempting options at ones' finger tips it is to some extent no wonder that people get distracted from their current work. Companies have had similar problems in the past with telephone usage where employees could not resist the telephone and spent large amounts of time talking to friends or accessing third party lines. Many companies have solved this problem by itemizing phone bills for each telephone extension within the organisation, making employees pay for personal calls, blocking out third party line access and blocking out international phone line access. All of these initiatives have made employees more aware of their telephone usage. This, combined with the knowledge that they are being monitored, has curbed the desire to abuse privileges. Again a "bit tax", in so far as it would introduce a "costing" element in Internet use, could provide an incentive for more efficient use of electronic communication at work. Taking networking privileges away is clearly not the answer since network access helps employees do there jobs better.

\section{By way of Conclusion: on possible uses of the "bit tax"}

Naturally, there are plenty of suggestions for spending the revenues collected from the "bit tax". The High Level Expert Group proposed the use of the tax as a means for financing the social security system in Europe. We will not extensively elaborate on this argument here. ${ }^{25}$ However, we will say that at the outset this seems to be the most logical step, given the distributional implications of the new information and communication technologies and the challenges the emerging Information Society is putting to social cohesion policies, particularly

\footnotetext{
24

For a more detailed argumentation on the employment aspects of the emerging information society, see Petit and Soete, 1996.
} 
in the European countries with highly developed but costly social welfare systems. On a priori grounds the use of the additional "bit tax" revenues to fund for instance the employers' social security contributions in countries like Belgium, the Netherlands, France, Italy or Germany should bring about a substantial reduction in labour costs, hence provide at least new incentives for job creation and improved competitiveness.

The impact of the "bit tax" on particular groups in society, sectors or firms, is something which remains very much an open issue and depends, as argued above, on the volume of tax revenues and the various responses by individuals and firms on a "bit tax" imposition. Obviously, the practical policy proposal should, as was also implicit in the High Level Expert Group report, be accompanied by measures that address the issue of IS "exclusion" and hence also possible exemption from a "bit tax".

Under the heading of "universal service obligation", the expert group considered this issue when they recommended the need: "...to investigate in much greater detail whether in order to avoid exclusion and preserve regional cohesion, the current notion of "universal service" should not be shifted in the direction of a notion of "universal community service", extending universal service provision to incorporate a basic level of access to new information services ${ }^{26}$ but limited in its universality obligation to educational, cultural, medical, social or economic institutions of local communities. Such a "community" USP concept would in effect mean a return to the historical notion of "universality" as introduced last Century in the US with the advent of the telegraph. It would guarantee open access to the network and the carrier services and involve, where necessary, public funding for technical and financial assistance." 27 Such universal community service obligation would practically by definition imply various possibilities for "bit tax" exemption (hospitals, education establishments, etc.), as is common with VAT today.

25 "This could be specified in functional rather than technical terms such as possibilities for electronic networking, data and mail interchanges, access to new business and information services available world wide and in core regions." of Experts, DG V, Brussels, January 1996, page 43. 
A "bit tax" could also be instrumental in resolving the intellectual property rights problems associated with the networks. In the information age this issue has grown in importance as it has become increasingly difficult to compensate individuals and organisations for their work. Via the networks an individual can deliver perfect copies of digitised work to countless others or upload a copy to a bulletin board or other service where thousands can download it or print hardcopies ${ }^{28}$. This issue is of obvious importance for compensation but also for network usage. Creators, publishers and distributors of output may become or are becoming wary of the networks unless tools are developed that compensate them for their work. Thus, if intellectual property right problems are not resolved, businesses, creators and other owners of intellectual property rights could be discouraged from selling on-line thus reducing network usage. Creators and other owners of intellectual property rights will not want to put their investments at risk. Since the "bit tax" would require usage to be "itemised" in some way, it could be developed to help collect intellectual property right fees. The idea here is similar to the small tax which exists in many countries on photocopying, representing a common payment for foregone copyrights.

But this is certainly not the place to elaborate on the possible uses of something so speculative and controversial as a "bit tax". The purpose of this short paper was to bring together some of the main arguments why there is, at least in our view, an urgent need for investigating the feasibility of such a new tax notion. Our hope was not to detract the many "criticasters" but rather that those Internet users, communication experts or policy makers who rejected the idea in an immediate, spontaneous, "cyber-like" fashion, might reflect a little longer on some of the arguments presented here. The volume and the speed of the reactions received so far have not succeeded in convincing us that there is a strong argument for not investigating the issue.

$27 \quad$ As Brody put it: "Want to mail a fund-raising appeal to 10,000 people? The Internet converts this from a $\$ 3,200$ postal endeavour into one that's more or less on the house. Internet users seem to have found a kind of surreal restaurant where they can order a bottomless cup of coffee or a lobster dinner for 100 friends and no one ever presents an itemized bill" op. cit., p.1 